\title{
Toll-like Receptor 2 Signalling and the Lysosomal Machinery in Barrett's Esophagus
}

\author{
Romy E. Verbeek ${ }^{1}$, Peter D. Siersema ${ }^{1,5}$, Frank P. Vleggaar ${ }^{1}$, Fiebo J. ten Kate ${ }^{2}$, George Posthuma ${ }^{3}$, Rhonda F. Souza ${ }^{4}$, \\ Judith de Haan', Jantine W.P.M. van Baal ${ }^{1}$
}

\author{
1) Department of \\ Gastroenterology and \\ Hepatology, \\ 2) Department of Pathology, \\ 3) Department of Cell \\ Biology, Center for Electron \\ Microscopy, \\ University Medical Center \\ Utrecht, Utrecht, \\ The Netherlands; \\ 4) Department of Medicine, \\ University of Texas \\ Southwestern Medical Center, \\ VA North Texas Health Care \\ System, Dallas, Texas, USA; \\ 5) Department of \\ Gastroenterology and \\ Hepatology, Radboud \\ University Medical Center, \\ Nijmegen, The Netherlands
}

\begin{abstract}
Background \& Aims: Inflammation plays an important role in the development of esophageal adenocarcinoma and its metaplastic precursor lesion, Barrett's esophagus. Toll-like receptor (TLR) 2 signalling and lysosomal function have been linked to inflammation-associated carcinogenesis. We examined the expression of TLR2 in the esophagus and the effect of long-term TLR2 activation on morphological changes and expression of factors involved in lysosomal function in a Barrett's esophagus epithelium cell line.

Methods: TLR2 expression in normal squamous esophagus, reflux esophagitis, Barrett's esophagus and esophageal adenocarcinoma biopsies was assessed with Q-RT-PCR, in situ hybridization and immunohistochemistry. Barrett's esophagus epithelium cells (BAR-T) were incubated with acid and bile salts in the presence or absence of the TLR2 agonist Pam3CSK4 for a period up to 4 weeks. Morphological changes were assessed with electron microscopy, while Q-RT-PCR was used to determine the expression of lysosomal enzymes (Cathepsin B and C) and factors involved in endocytosis (LAMP-1 and M6PR) and autophagy (LC3 and Rab7).

Results: TLR2 was expressed in normal squamous esophagus, reflux esophagitis, Barrett's esophagus but was most prominent in esophageal adenocarcinoma. Long-term TLR2 activation in acid and bile salts exposed BAR-T cells resulted in more and larger lysosomes, more mitochondria and increased expression of LAMP1, M6PR, Cathepsin B and C when compared to BAR-T cells incubated with acid and bile salts but no TLR2 agonist. Factors associated with autophagy (LC3 and Rab7) expression remained largely unchanged.

Conclusion: Activation of TLR2 in acid and bile salts exposed Barrett epithelium cells resulted in an increased number of mitochondria and lysosomes and increased expression of lysosomal enzymes and factors involved in endocytosis.
\end{abstract}

Key words: Barrett's esophagus - esophageal adenocarcinoma - Toll-like receptor 2 - lysosomes.

Abbreviations: BE: Barrett's esophagus; DCA: deoxycholic acid; EAC: esophageal adenocarcinoma; GCA: glycocholic acid; IL8: interleukin 8; IHC: immunohistochemistry; ISH: in situ hybridization; LAMP-1: lysosomal-associated membrane protein-1; LC3: microtubule-associated protein 1A/1B-light chain 3; M6PR: mannose-6-phosphate receptor; NF- $\kappa$ B: Nuclear Factor- $\kappa B$; PPIs: proton pump inhibitors; Q-RT-PCR: Quantitative reverse transcriptase polymerase chain reaction; RE: reflux esophagitis; SQ: normal squamous esophagus; TCDCA: taurochenodeoxycholic acid; TLR: Toll-like receptor; TNFa: tumor necrosis factor $\alpha$.

\section{INTRODUCTION}

Received: 09.04.2016

Accepted: 08.08.2016
The pathogenesis of esophageal adenocarcinoma (EAC) and its precursor lesion Barrett's esophagus (BE) is incompletely known. Since EAC is frequently detected at an advanced stage, the prognosis of patients with advanced EAC is still poor, with a 5-year overall survival rate of $10-20 \%[1,2]$. Barrett's esophagus is a premalignant condition of the distal part of the esophagus in which normal squamous epithelium is replaced by columnar-lined epithelium with characteristic goblet cells [3]. Both chronic inflammation and ongoing exposure to an acid and bile containing gastroesophageal refluxate are considered to be important pathogenic factors in the development of BE and EAC [3-5]. Toll-like receptor (TLR) 2 signalling and lysosomal function have been linked to inflammation associated carcinogenesis [6-10]. 
Reflux of acid and bile salts is known to induce apoptosis, in which lysosomal membrane disruption has previously been demonstrated to play a role [11]. In BE and upper gastrointestinal cancer, including EAC, altered lysosomal function and activity and expression of factors involved in the lysosomal pathway have been reported $[6,7,9,10]$. Lysosomes are intracellular organelles that are known to be involved in processing waste products and are important regulators in intracellular homeostasis [12]. The lysosomal pathway consists of endocytosis, autophagy and lysosomal degradation, in which endocytosis related factors lysosomal-associated membrane protein-1 (LAMP-1) and mannose-6-phosphate receptor (M6PR), autophagy related factors, microtubule-associated protein 1A/1B-light chain 3 (LC3) and Rab7 and lysosomal enzymes such as Cathepsin B and C are involved [12-16]. In rapidly growing malignancies, effective lysosomal function plays a crucial role [16].

TLR2 is an innate immune receptor, which is activated by microbial products obtained from gram-positive bacteria. Upon activation, a complex pro-inflammatory signalling pathway is activated [18]. The lysosomal pathway is crucial in appropriate TLR2 signalling and, additionally, TLR2 has previously been found to be associated with lysosomal function [19].

Based on the literature, we hypothesized that TLR2 activation plays a protective role in neoplastic progression in $\mathrm{BE}$, in which the lysosomal pathway may be involved. Data regarding the expression and function of TLR2 in the esophagus, including the effect of activation of its signalling pathway on the lysosomal pathway is limited. Unraveling this may gain more insight in the pathogenesis of $\mathrm{BE}$ and EAC. We examined the expression of TLR2 in the esophagus. Accordingly, the effect of long-term TLR2 activation on morphological changes and the expression of factors involved in lysosomal function in BE epithelium cells exposed to acid and bile salts were studied.

\section{METHODS}

\section{Biopsy specimens}

During routine upper endoscopy, tissue samples were obtained from patients with $\mathrm{BE}$ associated $\mathrm{EAC}, \mathrm{BE}$, reflux esophagitis (RE) and normal controls. Of the 10 EAC patients, 8 were male, mean age 69 years (range 51-87), 2 were diagnosed with tumor stage I, 3 with stage II, 3 with stage III, and 2 with stage IV and without prior treatment with radio- or chemotherapy. Of the $10 \mathrm{BE}$ patients, 7 were male, mean age 60 years (range 38-74), median BE segment length $3 \mathrm{~cm}$ (range 3-8), without (prior) dysplastic changes or ablative therapy and all used proton pump inhibitors (PPIs). Of the 10 RE patients, 5 were male, mean age 58 years (range 43-65), 6 used PPIs and 7 had grade A esophagitis according to the Los Angeles criteria, 2 grade $B$, and 1 grade $D$. Of the 10 normal controls, 6 were male, mean age 49 years (range 23-68) and all without reflux symptoms, PPI-use or endoscopic abnormalities. Paired biopsies were collected from EAC, BE and normal squamous esophagus (SQ) tissue $\geq 3 \mathrm{~cm}$ above the gastro-esophageal junction. The RE biopsies were taken next to the erosions. Duodenum biopsies were collected from BE patients as a positive control for intestinal type of epithelium.
To study TLR2 expression at the mRNA and protein level, one biopsy was snap frozen in liquid nitrogen and stored at $-80^{\circ} \mathrm{C}$ for subsequent RNA isolation and one biopsy was fixed in formalin and embedded in paraffin for histopathological evaluation, immunohistochemistry (IHC) and in situ hybridization (ISH). The Medical Ethical Committee of the University Medical Center Utrecht approved the study on September 30, 2009 and all patients signed informed consent.

\section{Cell culture}

The human telomerase-immortalized non-neoplastic Barrett epithelium cell line BAR-T was kindly provided by Dr. R.F. Souza and grown in a special supplemented keratinocyte basal medium-2 (Lonza, Breda, The Netherlands) according to Jaiswal et al. [21, 22]. The human embryonic kidney cell line HEK293 does not express TLR2 and was accordingly used as a negative control and cultured as described previously [22].

\section{Short-term TLR2 stimulation}

To evaluate the effect of TLR2 activation, BAR-T in HEK293 cells were incubated for 24 hours with the synthetic TLR2 agonist Pam3CSK4 (Invitrogen, San Diego, CA, USA) [23] at concentrations of $12.5,25,50$ and $100 \mathrm{ng} / \mathrm{ml}$. Incubation with $20 \mathrm{ng} / \mathrm{ml}$ recombinant human tumor necrosis factor alpha (TNF $\alpha$ R\&D Systems Europe Ltd, Oxon, UK) was included as a positive control for NF- $\kappa \mathrm{B}$ activation. Supernatant was collected and total RNA was isolated, in order to determine TLR2 and interleukin 8 (IL8) mRNA expression and IL8 secretion. Experiments were performed three times in duplicate.

\section{Long-term TLR2 stimulation combined with acid and} bile salts

BAR-T cells were incubated for 4 weeks with acid and bile salts with or without the TLR2 agonist, to determine the effect of long-term TLR2 activation on morphological changes in BE cells exposed to acid and bile salts. Four experimental conditions were included: blanc, TLR2 agonist, acid and bile salts and TLR 2 agonist combined with acid and bile salts. Two concurrent experiments were performed in duplicate. In T25 cell culture flasks, $1.7 \times 10^{\wedge} 5$ BAR-T cells were cultured in supplemented keratinocyte basal medium-2 with or without $12.5 \mathrm{ng} / \mathrm{ml}$ of the TLR2 agonist Pam3CSK4. The appropriate BAR-T samples were 4 times per week exposed to a $200 \mu \mathrm{M}$ bile salts mixture composed of $25 \%$ deoxycholic acid (DCA), $45 \%$ glycocholic acid (GCA) and 30\% taurochenodeoxycholic acid (TCDCA) at $\mathrm{pH} 4$ for 5 minutes (Fig. 1). This acid and bile salts mixture was chosen based on previous studies and were optimized in cell culture experiments (data available upon request) [24-26]. Subsequently, samples were washed and culture medium with or without the TLR2 agonist was added. Cells were subcultured weekly. After 3 weeks, BAR-T samples were duplicated during subculturing; one sample was used for mRNA isolation and the other sample for electron microscopy (EM) at the end of the cell culture experiment at 4 weeks and culture medium of all samples was collected for enzyme linked immuno-sorbent assay (ELISA).

Quantitative reverse transcriptase polymerase chain reaction (Q-RT-PCR)

Total RNA isolation from biopsies and BAR-T cells, measurement of RNA concentrations, confirmation of RNA 


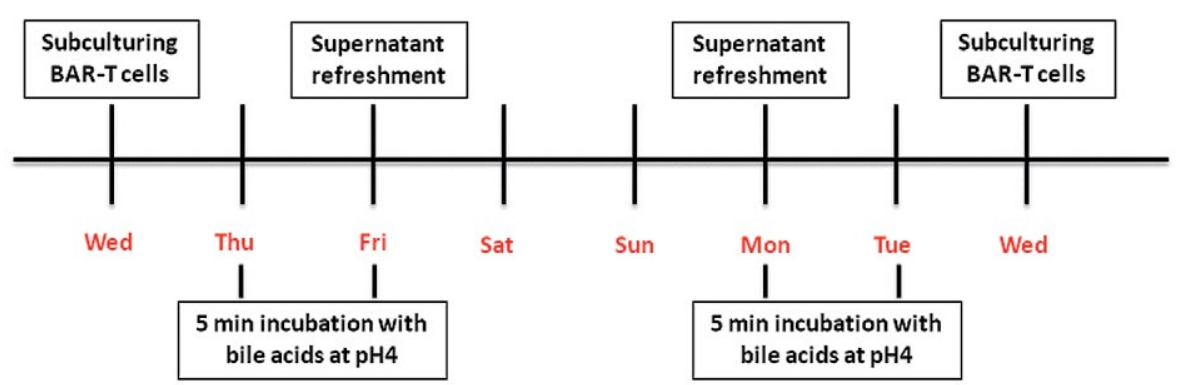

Fig. 1. Long-term incubation of BE epithelium cells with TLR2 agonist Pam3CSK4 and acid and bile salts. Time line of the stimulation of BAR-T cells with the TLR2 agonist Pam3CSK4, acid and bile salts for 4 weeks. BAR-T cells were cultured with or without $12.5 \mathrm{ng} / \mathrm{ml} \mathrm{Pam3CSK} 4$. On Wednesday BAR-T cells were subcultured. The appropriate samples were incubated for 5 minutes with acid and bile salts mixture (200 $\mu \mathrm{M} ; 25 \%$ DCA, $45 \%$ GCA and 30\% TCDCA at pH 4$)$ on Thursday, Friday, Monday and Tuesday.

integrity, cDNA synthesis and Q-RT-PCR reactions were performed as previously described [22]. The primers (Table I) were mRNA specific to prevent signal information from contaminating genomic DNA. Using Taqman probes, LC3 (Hs01076567_g1) and 2 endogenous reference genes were measured, i.e. GAPDH (Hs 4333764F) and $\beta$-2-microglobulin (Hs 4333766F) (Applied Biosystems, Foster City, CA, USA). All cDNA samples were analyzed in duplicate. The amplification results of the genes of interest were normalized to the mean value of corresponding GAPDH and $\beta$-2-microglobulin results using the $\Delta \mathrm{Ct}$ method [27]. Data were expressed relative to the mean $\Delta \mathrm{Ct}$ of SQ biopsies, to the control BAR-T cells not incubated with the TLR2 agonist (short-term cell culture experiment) or to the BAR-T cells incubated with acid and bile salts (long-term cell culture experiment), whenever appropriate.

\section{TLR2 in situ hybridization (ISH)}

TLR2 ISH was performed on $6 \mu \mathrm{m}$ paraffin-embedded EAC, BE, SQ, RE and duodenum tissue sections as previously described [22]. A fluorescein labeled human TLR2 specific locked nucleic acid (LNA) and 2'-O-methyl-RNA (2OME) probe (5'-TagCucTguAgaTcuGaaG- 3', with LNA residues in upper case and 2OME in lower case; 100uM 1:100 Ribotask ApS, Odense, Denmark) was used. The final signal was visualized using the VECTOR Blue AP Substrate Kit (Vector Laboratories, Burlingame, CA, USA); no counterstain was applied. Control slides in which the TLR2 probe was omitted were included (data not shown).

\section{TLR2 immunohistochemistry (IHC)}

TLR2 IHC was performed as previously described, with subsequent incubation of polyclonal goat anti-human TLR2 1:600 (Abcam, Cambridge, UK), biotinylated horse anti-goat, streptavidin-biotinylated horse radish peroxidase (Dako, Glostrup, Denmark), NovaRed as a chromogen substrate and haematoxylin as a counterstain (Vector Laboratories) [22]. No staining was observed in negative control slides in which the TLR2 antibody was omitted (data available on request). In control immunofluorescence experiments, the specificity of the TLR2 antibody was evaluated. TLR2 expression was absent in the negative control cells HEK293, whereas strong expression was observed in EAC cells (OE33; data available on request).

\section{Enzyme linked immunosorbent assay (ELISA)}

Upon short-term (24 hours) and long-term (4 weeks) incubation with the TLR2 agonist, Pam3CSK4, we measured IL8 concentrations in the cell culture supernatant by ELISA (BD OptEIA ${ }^{\mathrm{m}}$, San Diego, CA, USA). Absorbance was read at $450 \mathrm{~nm}$ on a spectrophotometric plate reader using the Microplate manager 5.2 software program (BioRad). All experiments were performed in duplicate and the average of two readings was calculated.

\section{Electron microscopy (EM)}

After 4 weeks of incubation of BAR-T cells with the TLR2 agonist Pam3CSK4, and acid and bile salts, a chemical fixative (2\% formaldehyde, $2.5 \%$ glutaraldehyde in $0.1 \mathrm{M}$ $\mathrm{Na}$-cacodylate buffer, $\mathrm{pH}$ 7.4) was added to the culture flasks

Table I. Primer sequences used for Q-RT-PCR with corresponding annealing temperature.

\begin{tabular}{lccc}
\hline Target & Forward primer & Reverse primer & Annealing T (30 sec) \\
\hline TLR2 & TTTCACTGCTTTCAACTGGTA & TGGAGAGGCTGATGATGAC & $57^{\circ} \mathrm{C}$ \\
IL8 & CACCGGAAGGAACCATCTCACT & TGCACCTTCACACAGAGCTGC & $62^{\circ} \mathrm{C}$ \\
Cathepsin B & AGTGGAGAATGGCACACCCTA & AAGAAGCCATTGTCACCCCA & $58^{\circ} \mathrm{C}$ \\
Cathepsin C & CGGCTTCCTGGTAATTCTTC & GTGGTCCCATAACCGAGCAG & $58^{\circ} \mathrm{C}$ \\
LAMP-1 & AACTTCTCTGCTGCCTTCTC & GAGTGAGTGTATGTCCTCTTCC & $58^{\circ} \mathrm{C}$ \\
M6PR & AATCGACACACCCTAGCGGACAAT & CAGCAACCAGTGATGCAAACGTGA & $60^{\circ} \mathrm{C}$ \\
Rab7 & AGTTCCCTGGAACCAGAACTTGGA & TGTGACTAGCCTGTCATCCACCAT & $58^{\circ} \mathrm{C}$ \\
\hline
\end{tabular}


for 2 hours at room temperature to preserve the cellular morphology. Subsequently, the fixative was replaced by $0.1 \mathrm{M}$ Na-cacodylate buffer, $\mathrm{pH}$ 7.4. The cells were removed from the culture flask using a cell scraper and transferred to an Eppendorf vial (Eppendorf, Nijmegen, The Netherlands). After mild centrifugation, the supernatant was removed and the cells were resuspended in 1\% agarose LM-MP (Roche, Woerden, the Netherlands) at $37^{\circ} \mathrm{C}$. After centrifugation the agarose was solidified on ice and the cell pellet was cut into $1 \mathrm{~mm}^{3}$ blocks. Then cells were postfixed with $1 \% \mathrm{OsO} 4$ and $1.5 \% \mathrm{~K} 3 \mathrm{Fe}(\mathrm{CN}) 6$ in $0.065 \mathrm{M} \mathrm{Na}$-cacodylate for 2 hours at $4^{\circ} \mathrm{C}$. After dehydration with ethanol the blocks were embedded in EPON according to standard procedures. Ultrathin sections $(50-70 \mathrm{~nm})$ were prepared on a Leica Ultracut S (Leica, Vienna, Austria) and stained with uranylacetate and lead citrate using the Leica AC20 (Leica, Vienna, Austria). Fifteen random micrographs per experimental condition were taken on a Tecnai 12 (FEI, Eindhoven, The Netherlands) equipped with a SIS Megaview III. A mean of 2 cells were visible on a micrograph. The volume densities of different organelles were blindly measured (R.V.) and revised by an independent experienced observer (G.P.) with point-hit using a simple square lattice test system in Image $\mathrm{J}(\mathrm{NIH}$, Bethesda, MD, USA) with a grid plugin $(\mathrm{d}=0.8 \mu \mathrm{m}$; Fig. 4c) [28]. The same lattice was used to measure intersections with membranes to evaluate the length density of membranes.

\section{Statistical analysis}

IL8 secretion (ELISA) and all mRNA expression data were presented as mean \pm standard error of the mean (SEM). Data were compared between the two groups of cell line samples and biopsies using two-tailed $t$ tests and between multiple groups using ANOVA. A level of $\mathrm{p}<0.05$ was considered statistically significant. SPSS software version 15.0 for Windows (SPSS Inc, Chicago, IL, USA) and GraphPad Prism version 5.0 (GraphPad Software, San Diego, CA, USA) were used for the statistical analyses.

\section{RESULTS}

\section{TLR2 expression in the esophagus}

TLR2 mRNA expression was examined in human esophageal biopsies using Q-RT-PCR. TLR2 expression was 3.6-fold increased in EAC (3.62 \pm 0.91$)$ compared to SQ $(1.00 \pm 0.09, \mathrm{p}=0.02$; Fig. 2a). TLR2 mRNA expression was $2.09 \pm 0.66(\mathrm{p}=0.09)$ fold increased in BE and $1.47 \pm 0.38(\mathrm{p}=0.2)$ fold in RE compared to SQ. TLR2 mRNA expression was most evident in nuclei, but also in cytoplasm and in both epithelium and lamina propria cells (Fig. 2b). As confirmed by ISH, TLR2 mRNA expression was largely confined to the basal layer of the epithelium, whereas in BE and EAC a more diffuse expression pattern throughout the biopsy was observed.

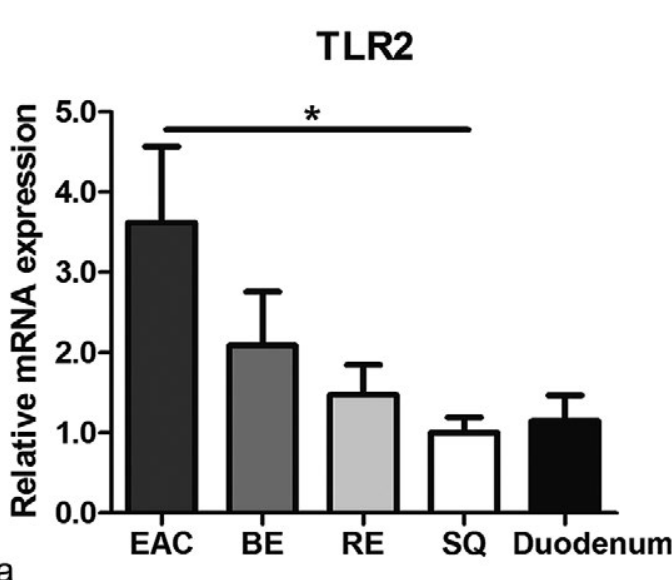

a

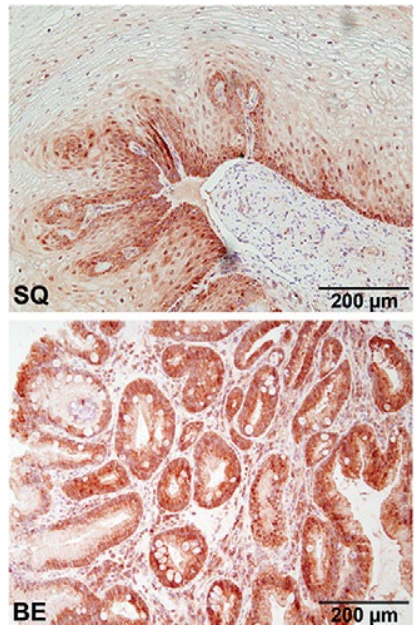

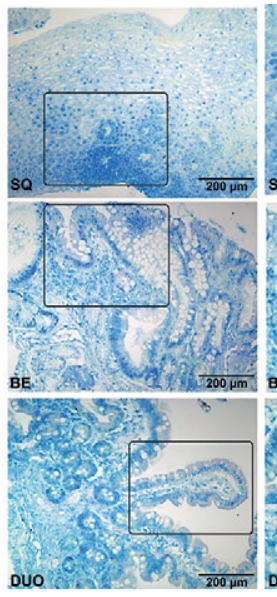
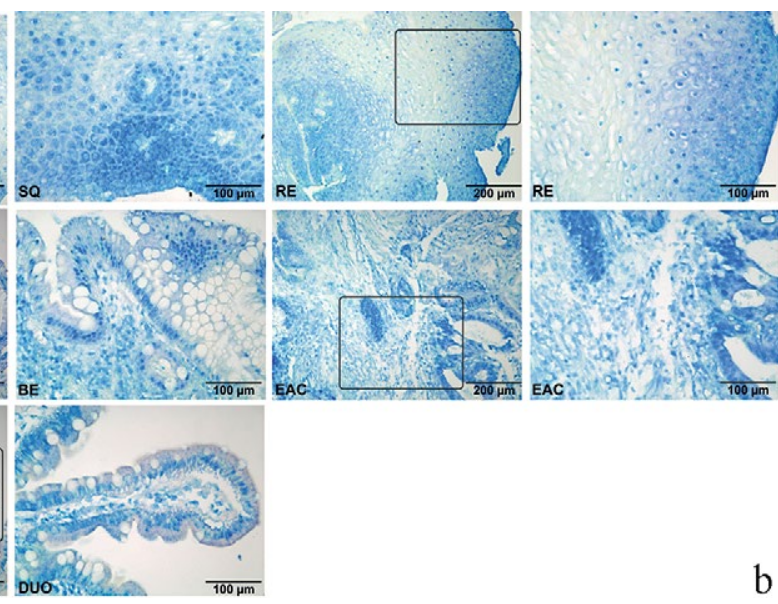

Fig. 2. TLR2 mRNA and protein expression in esophageal biopsies. a) Q-RT-PCR showed that TLR2 $\mathrm{mRNA}$ expression was significantly increased in EAC compared to SQ biopsies. In BE and RE biopsies TLR2 expression was not significantly different compared to SQ. TLR2 expression in BE was not significantly different compared to duodenum. Number of patients: 10 per subgroup. Experiments were performed in duplicate. GAPDH and $\beta$-2-microglobulin were used for normalization. Data are expressed as mean \pm SEM, relative to the mean $\Delta \mathrm{Ct}$ of $S Q$ biopsies. Two-tailed t tests were used; ${ }^{*} p<0.05$. b) ISH showed evident expression of TLR2 mRNA in nuclei and in cytoplasm in SQ, RE, BE and EAC biopsies. TLR2 expression was seen in superficial epithelial cells, deeper crypts and lamina propria cells. Expression in duodenum corresponded to BE. No counterstain was used. c) IHC showed predominant expression of TLR2 in the basal keratinocytes in SQ, whereas in RE TLR2 expression reached up to the more superficial layer of the squamous epithelium. In BE, TLR2 expression was most prominent in superficial epithelial cells and deeper crypts, but also observed in lamina propria cells. In EAC, diffuse expression throughout the biopsy was observed. Haematoxylin counterstain was used. ISH and IHC pictures are representative for all cases. Number of patients: 10 per subgroup. 

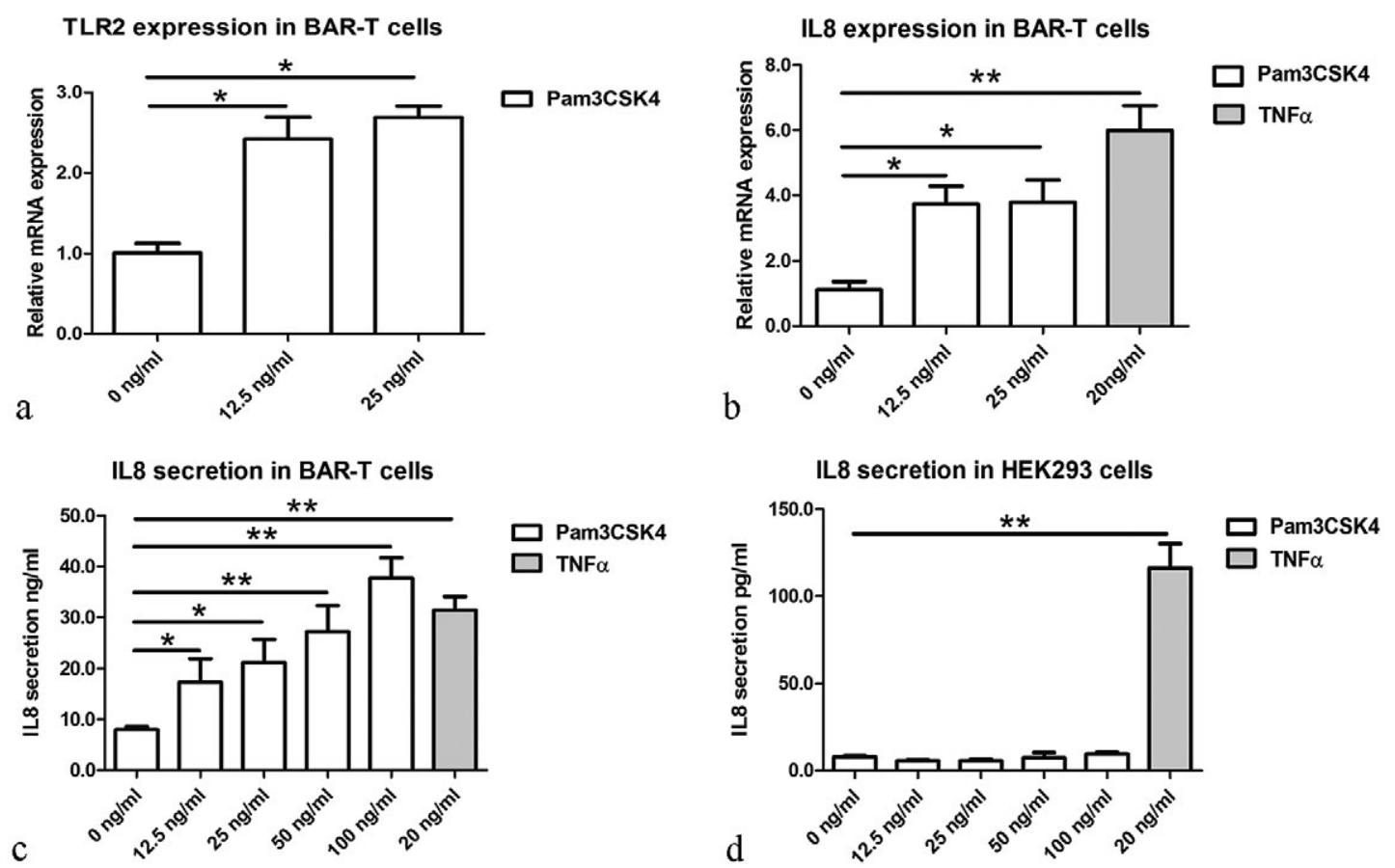

Fig. 3. The effect of short-term TLR2 activation in BE epithelium cells. a) Q-RT-PCR showed that TLR2 mRNA expression was significantly increased in BAR-T cells incubated with Pam3CSK4 for 24 hours compared to control cells not incubated with Pam3CSK4. b) Q-RT-PCR showed that IL8 mRNA expression was significantly increased in BAR-T cells incubated with Pam3CSK4 for 24 hours compared to control cells. In addition, BAR-T cells incubated with TNFa also showed an increased IL8 expression. c) ELISA showed a dose-dependent increase in IL8 secretion in the cell culture supernatant of BAR-T cells upon 24 hours of Pam3CSK4 incubation. In positive control cells incubated with TNFa, IL8 secretion was also increased. d) In negative control cells HEK293, IL8 secretion was not increased upon Pam3CSK4 incubation. Experiments were performed 3 times in duplicate. Data were normalized to control samples not incubated with Pam3CSK4. In Q-RT-PCR experiments GAPDH and $\beta$-2-microglobulin were used for normalization. ${ }^{\star} \mathrm{p}<0.05,{ }^{* *} \mathrm{p}<0.01$.

Immunostaining showed predominant expression of TLR2 in the basal keratinocytes in SQ, whereas in RE, TLR2 expression was observed around the papillae high up in the epithelium due to papillary hyperplasia. In BE, TLR2 expression was most prominent in superficial epithelial cells and deeper crypts, but was also observed in lamina propria cells. In EAC, diffuse TLR2 expression was observed (Fig. 2c).

\section{The effect of TLR2 stimulation in BE epithelium cells}

Upon short-term (24 hours) incubation with the TLR2 agonist Pam3CSK4 in BE epithelium cells (BAR-T), upregulation of TLR2 mRNA expression was observed (Fig. 3a). Additionally, Pam3CSK4 incubation resulted in a significant increase in IL8 mRNA expression and a dosedependent increase in IL8 secretion in BAR-T cells (Fig. 3b, c). These results illustrate that an inflammatory response is induced upon TLR2 activation in non-neoplastic BE cells. As expected, IL8 secretion was not increased in the negative control cells line HEK293, which do not express TLR2, following incubation with the TLR2 agonist (Fig. 3d).

TLR2 activation in BE epithelium cells after long-term exposure to acid and bile salts

After 4 weeks of repeated exposure of BAR-T cells to acid and bile salts, using $200 \mu \mathrm{M}$ bile salts mixture composed of $25 \%$
DCA, $45 \%$ GCA and 30\% TCDCA at pH 4, in the presence or absence of the TLR2 agonist (12.5 ng/ml Pam3CSK4), RNA was isolated, cells were fixated for EM and culture medium was collected.

Increased IL8 mRNA expression and secretion was observed in BAR-T cells incubated with both acid and bile salts and the TLR2 agonist compared to control cells (Fig. 4a, b). The effect of short-term ( 24 hours) exposure to TLR2 agonist and acid and bile salts is shown in Supplemental Fig. 1.

Morphological changes were evaluated using EM. An initial screening of the EM images evidenced few differences between experimental conditions. The BAR-T cells looked vital and no apoptotic changes were observed: no abnormal nuclear content, chromatin condensation or nucleolus segregation and no swelling of mitochondria and cellular shrinkage were observed (data not shown). Stereological methods revealed that a larger proportion of the cell volume consisted of vehicles from the endocytic pathway (early endosomes, multivesicular bodies and lysosomes together) in BAR-T cells incubated with both the TLR2 agonist and acid and bile salts compared to BAR-T cells incubated with the TLR2 agonist or acid and bile salts alone (Fig. 4c, d, e). Additionally, a larger proportion of the cell volume consisted of mitochondria in BAR-T cells incubated with both the TLR2 agonist and acid and bile salts compared to BAR-T cells incubated with acid and bile salts alone $(\mathrm{p}=0.02)$ (Fig. 4f). Volume densities of endoplasmic reticulum, Golgi 

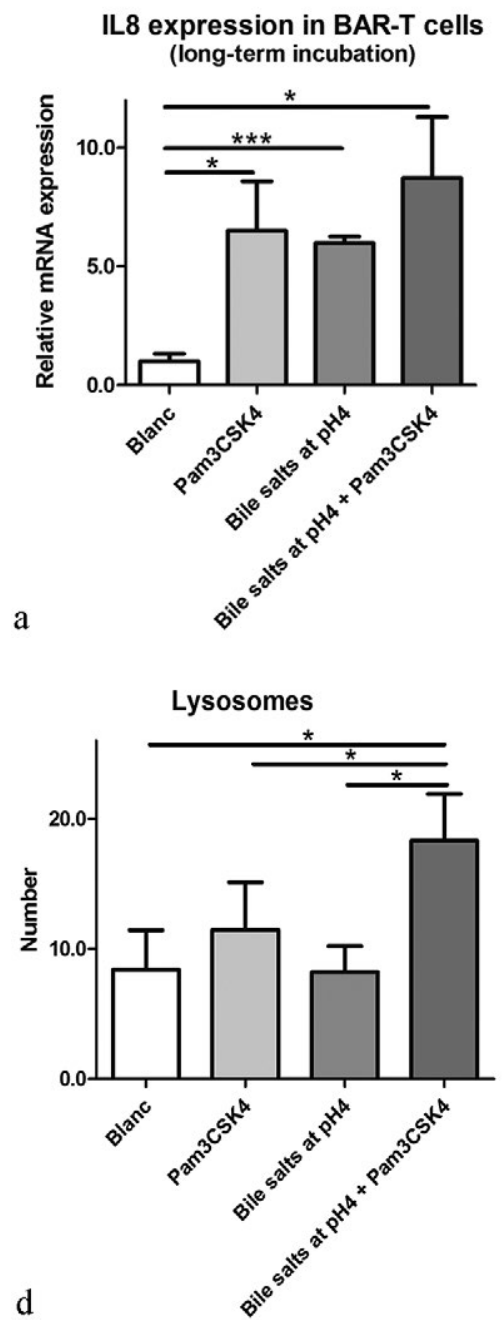
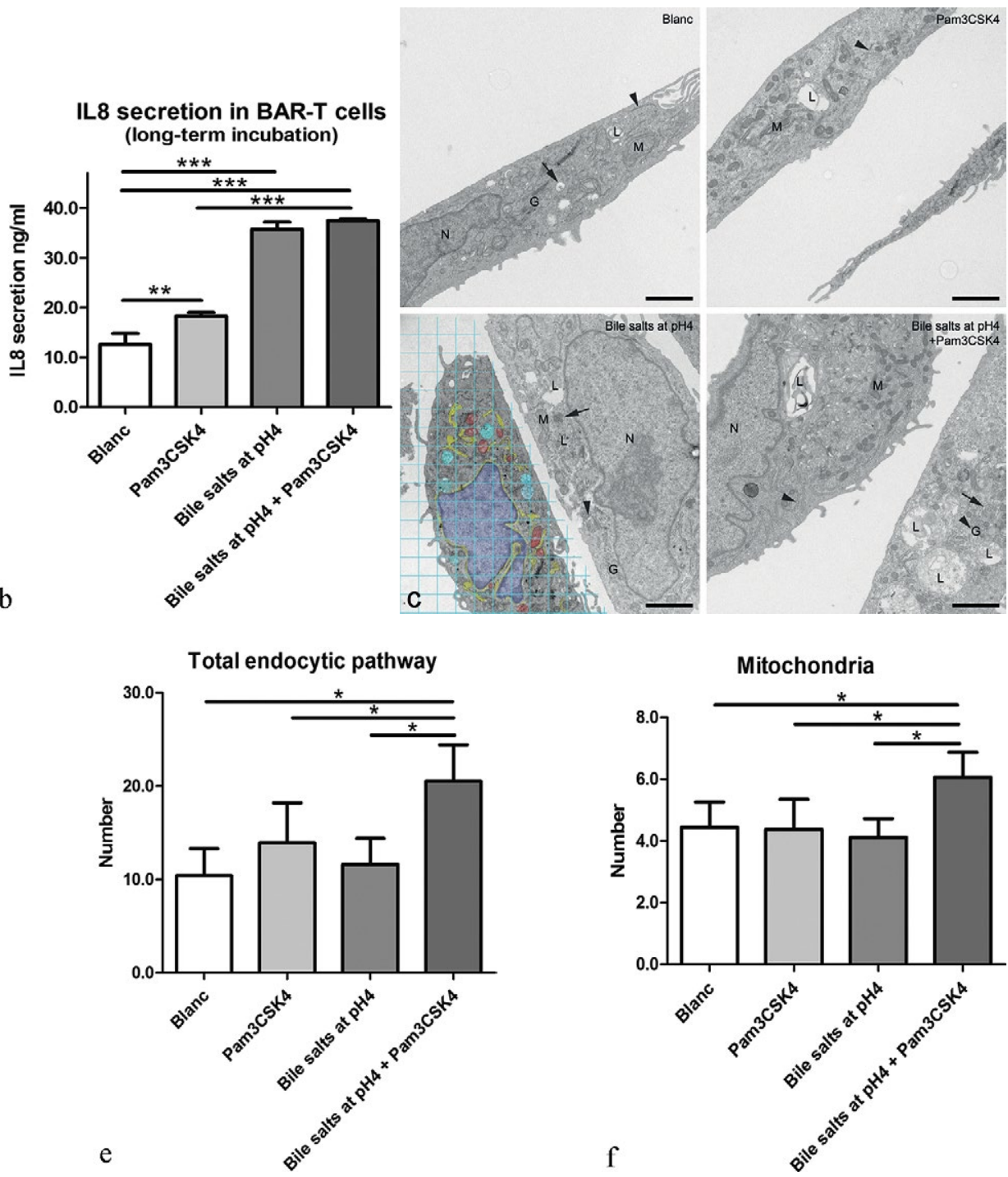

Fig. 4. Morphological changes upon long-term TLR2 stimulation in BE epithelium cells. a) Q-RT-PCR showed that IL8 mRNA expression was significantly increased in BAR-T cells incubated with $12.5 \mathrm{ng} / \mathrm{ml}$ of the TLR2 agonist Pam3CSK4, acid and bile salts mixture $(200 \mu \mathrm{M}$; 25\% DCA, 45\% GCA and 30\% TCDCA at pH 4) and with both acid and bile salts mixture and Pam3CSK4 for 4 weeks compared to control cells. b) ELISA showed an increase in IL8 secretion in the cell culture supernatant of BAR-T cells incubated with 12.5ng/ml Pam3CSK4, acid and bile salts and both Pam3CSK4 and acid and bile salts for 4 weeks compared to control cells. c) In BAR-T cells incubated with Pam3CSK4 and acid and bile salts, more and/or larger lysosomes and mitochondria were observed compared to BAR-T cells incubated with acid and bile salts and Pam3CSK4 alone. Representative EM images are demonstrated. In the bottom left panel some organelles have been coloured and the square lattice test system to measure volume densities is depicted. $\mathrm{G}=$ golgi complex, $\mathrm{L}=$ lysosome, $\mathrm{M}=$ mitochondrium (red), $\mathrm{N}=$ nucleus (purple), arrow=multivesicular body (blue), arrowhead=endoplasmic reticulum (yellow). d) A larger proportion of the cell volume consisted of lysosomes in BAR-T cells incubated with both the TLR2 agonist and acid and bile salts compared to cells incubated with acid and bile salts alone. e) A larger proportion of the cell volume consisted of compartments of the endocytic pathway (early endosomes, multivesicular bodies and lysosomes together) in BAR-T cells incubated with both the TLR2 agonist and acid and bile salts compared to cells incubated with acid and bile salts alone. f) A larger proportion of the cell volume consisted of mitochondria in BAR-T cells incubated with both the TLR2 agonist and acid and bile salts compared to cells incubated with acid and bile salts alone; a non-significant increase was observed compared to the TLR2 agonist alone and control BAR-T cells. Number of images analyzed: 15 per experimental condition. ${ }^{\star} \mathrm{p}<0.05,{ }^{\star *} \mathrm{p}<0.01,{ }^{\star * *} \mathrm{p}<0.001$.

complex, calveoli, filaments, cytoplasm and nucleus were not significantly different. The total volume of BAR-T cells, represented by the total number of counted points, was the same for the various experimental conditions (data not shown).

\section{Expression of factors involved in lysosomal function}

Expression of lysosomal enzymes and factors involved in endocytosis and autophagy were determined upon incubation of BE cells with acid and bile salts in the presence or absence of the TLR2 agonist Pam3CSK4 for 4 weeks. Q-RT-PCR results indicated a significantly increased expression of the lysosomal enzymes Cathepsin B and C upon incubation with Pam3CSK4 in combination with acid and bile salts compared to BAR-T cells incubated with acid and bile salts or Pam3CSK4 alone (Fig. 5a, b). In addition, expression of LAMP-1 and M6PR, factors associated with endocytosis, was significantly increased in BAR-T cells incubated with acid, bile salts and Pam3CSK4 (Fig. 5c, d). This effect was 

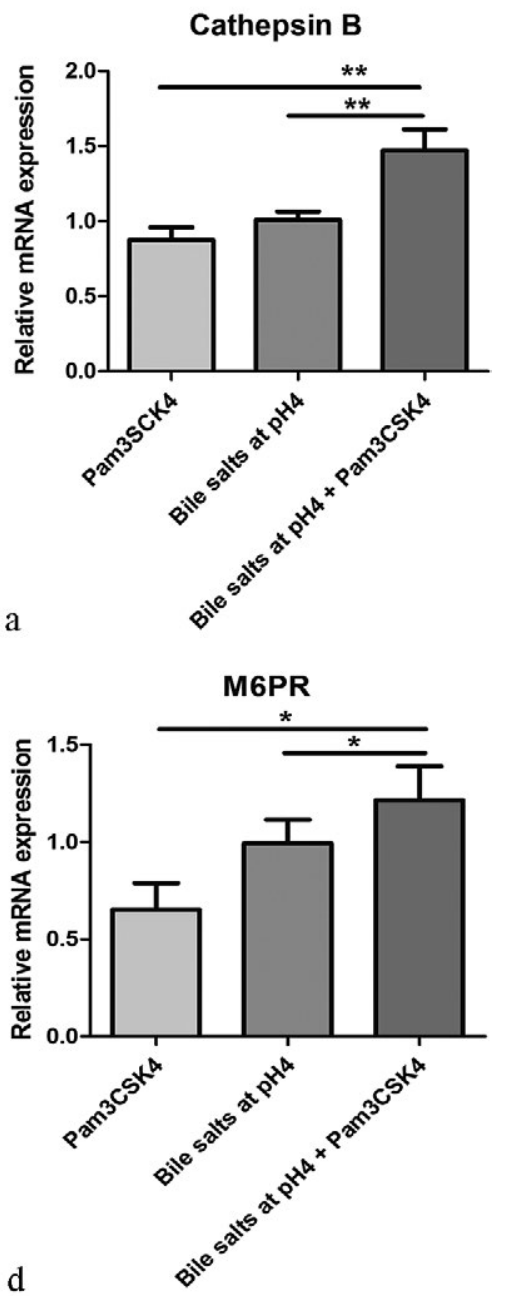

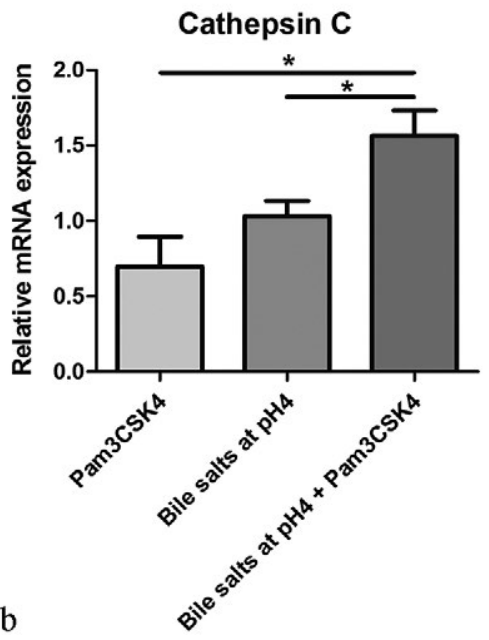

Rab7

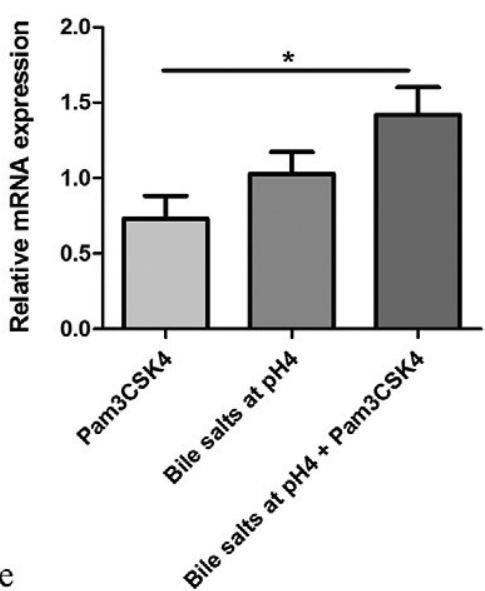

LAMP-1

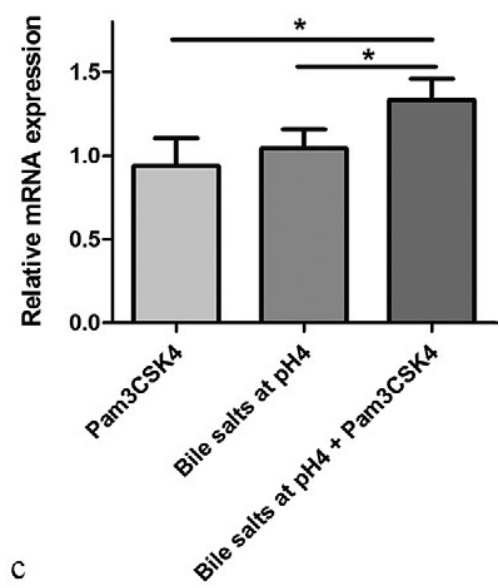

LC3

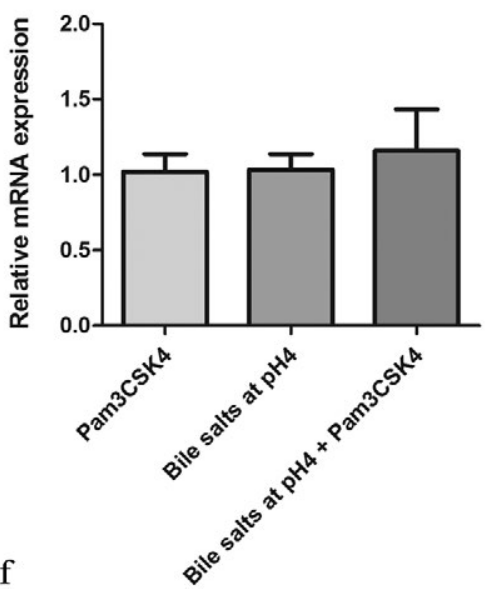

Fig. 5. Expression of factors involved in lysosomal function. Q-RT-PCR showed significantly increased Cathepsin B, C, LAMP1 and M6PR expression in BAR-T cells incubated with Pam3CSK4 in combination with acid and bile salts compared to cells incubated with acid and bile salts or Pam3CSK4 alone (a, b, c, d). Rab7 expression was increased in cells incubated with both Pam3CSK4 and acid and bile salts compared to cells incubated with Pam3CSK4 alone (e). No difference in LC3 expression was observed (f). Expression data were normalized to BAR-T cells incubated with acid and bile salts. ${ }^{\star} \mathrm{p}<0.05,{ }^{\star *} \mathrm{p}<0.01$.

less evident when analyzing the expression of autophagy associated factor Rab7 and no difference in LC3 expression was observed (Fig. 5e, f).

\section{DISCUSSION}

This study demonstrates the TLR2 expression in normal SQ, $\mathrm{RE}, \mathrm{BE}$ and most prominent in EAC biopsies, in both immune and epithelial cells. Previous studies have shown the expression of TLR2 (and TLR1, TLR3 and TLR5) in SQ [29] and TE-1 (and TLR3, TLR4 and TLR7) in an esophageal squamous cell carcinoma cell line [30]. Huhta et al. recently demonstrated a slight increase in TLR2 expression from SQ towards intestinal metaplasia, dysplasia and EAC [31]. These findings largely correspond to the results of the present study. Differential expression and signalling of TLRs have been demonstrated in various gastrointestinal diseases, resulting in host protection through the induction of immune responses and damage repair processes. In addition, simultaneous stimulation of carcinogenesis has been observed [18, 22, 32, 33].

TLR2 is a pattern recognition receptor, which is activated by lipoproteins and peptidoglycans from gram positive bacteria and endogenous ligands released by stressed tissue [18]. The TLR2 agonist Pam3SCK4 used in the present study is a synthetic lipoprotein, which preserved most of the immune modulatory effects of its natural lipoproteins [23]. Previous studies have shown colonizing of gram-positive bacteria in the esophagus, which were predominantly present in SQ [34, 35]. In RE and $\mathrm{BE}$, a switch towards a more gram-negative microbiome has been observed [34-36]. In addition to microbial products, endogenous heat shock proteins and high mobility group box 1 protein have been found to be capable of enhancing TLR2 signalling through binding to bacterial lipopeptide [37]. These data suggest that both exogenous and endogenous ligands contribute to TLR2 signalling in the esophagus. Previous studies have shown that TLR2 plays a protective role in intestinal inflammation. TLR2 is upregulated in the inflamed intestine, protecting gut mucosa by maintaining the gap junction structure and intercellular communication between intestinal epithelial cells during acute damage [38]. A study by Lowe et al. demonstrated that TLR2 protects against tumor development in mice in a colitis-induced cancer model by maintaining the epithelial homeostasis and reducing the inflammation [8]. 
IL8 expression and secretion, which were used as a readout for the induction of an inflammatory response, were increased following TLR2 stimulation in BE (BAR-T) cells. Interestingly, IL8 secretion had previously been found to be induced in esophageal squamous cell carcinoma cell lines (TE-1 and TE-7) upon TLR2 activation, which was not shown in SQ cells (primary squamous epithelium cells, EPC2 and EPC2-hTERT) [29, 39].

The effects of long-term TLR2 activation on morphological changes and the expression of factors involved in lysosomal function in BE epithelium cells exposed to acid and bile salts were studied. The lysosomal pathway consists of endocytosis, a process starting with early endosomes, represented by the cytoplasmic domain of cell membrane proteins, which is internalized into vesicles with ingested extracellular material [14]. M6PR is found on late endosomes, a subsequent compartment of the degradation pathway, and binds to lysosomal proteins emitting from the Golgi complex [12, 13]. M6PR is mutated or downregulated in various malignancies [17]. LAMP-1 is a transmembrane protein, highly enriched in both late endosomes and lysosomes [15]. Autophagy is responsible for the degradation of intercellular components, in which LC3 and Rab7 are involved [12]. Endosomes and autophagosomes either traffic to lysosomes and fuse with the lysosomal limiting membrane, comprising a degradation machinery constituted of catalytic enzymes, such as cathepsins, or endosomes are subject to a recycling process $[14,16]$. In the present study, long-term TLR2 stimulation in acid and bile salts exposed BE (BAR-T) cells resulted in increased numbers and larger volumes of lysosomes, more mitochondria, and upregulated expression of the lysosomal enzymes Cathepsin B and $\mathrm{C}$ and endocytosis associated factors LAMP-1 and M6PR. This effect was not observed in BE epithelium cells incubated with acid and bile salts or the TLR2 agonist alone. Only a change in Rab7 expression was observed in cells incubated with acid, bile salts and TLR2 agonist compared to cells incubated with TLR2 agonist alone. No difference in the expression of LC3 was observed. Our results may suggest that induction of lysosomal activity and endocytosis upon TLR2 signalling in combination with acid and bile salts exposure may also occur in BE. To our knowledge, the association between TLR2 signalling and lysosomal function in the esophagus has not been reported before.

TLR2 signalling was previously found to facilitate autophagy dependent nuclear factor $-\kappa \mathrm{B}(\mathrm{NF}-\kappa \mathrm{B})$ activation in bone marrow-derived macrophages [19]. The lysosomal compartment plays an important role in tissue homeostasis and cellular function, including processing exogenous material and recycling damaged organelles and molecules $[12,13,16,40]$. The suggested induction of lysosomal activity and endocytosis following TLR2 signalling in the presence of acid and bile salts may increase degradation of waste products and elimination of luminal danger signals in BE. Accordingly, effective lysosomal function is crucial in malignancies to facilitate survival and rapid growth of cancer cells [16]. Previous studies have shown that changes in lysosomal function are involved in carcinogenesis. Cathepsin B overexpression has been demonstrated to attribute to the invasive and metastatic potential of malignancies, e.g. in pancreatic and prostate cancer
$[41,42]$. In adenocarcinomas of the gastro-esophageal junction, increased Cathepsin B activity was found to correlate with lymph node involvement [6].

The strength of this study is the incorporation of a long term cell culture experiment for a period up to four weeks and the use of EM to assess morphological changes after stimulation with the TLR2 agonist in combination with acid and bile salts in a BE cell line. However, there are also some limitations in this study. We determined the effect of TLR2 signalling in combination with acid and bile salts incubation on mRNA expression of factors involved in the lysosomal pathway ex vivo. Future experiments should focus on functional activity assays or protein expression analyses in vivo. Furthermore, this study did not demonstrate an actual protective effect or 'healthier' phenotype as a result of the induction of lysosomal activity and endocytosis upon TLR2 stimulation in acid and bile salts exposed BE epithelium cells. In the future, the pathophysiological association between TLR2 and lysosomal function and the effect of the induction of lysosomal activity and endocytosis accompanying TLR2 activation in the presence of acid and bile salts in BE and the effect on cellular phenotype needs to be further elucidated, using additional cell lines, organoids [43] and/or animal models.

\section{CONCLUSION}

TLR2 signalling in acid and bile salts exposed BE epithelium cells resulted in an increased expression of lysosomal enzymes and accompanying factors involved in endocytosis. This observation, together with an increased number of mitochondria and extended numbers and larger volumes of lysosomes, may suggest the induction of lysosomal activity and endocytosis following TLR2 signalling in the presence of acid and bile salts. Interestingly, these results support a possible role of the innate immune system in $\mathrm{BE}$, in that TLR2 activation in BE (during reflux episodes) may increase clearing of waste accumulations, contributing to cellular homeostasis and defence, and thus might be involved in the protection against EAC development in BE.

Conflicts of interest. None to declare.

Acknowledgements. The authors thank Kees Fluiter (Dept. of Neurogenetics, Academic Medical Center, University of Amsterdam, Amsterdam, The Netherlands) for the assistance with TLR2 ISH.

Authors' contribution: R.E.V.: study concept and design, analysis and interpretation of data, statistical analysis, drafting of the manuscript; P.D.S.: study supervision, interpretation of data, critical revision; F.P.V.: material support; F.J.ten K.: analysis and interpretation of data; G.P.: technical support, revision of data; R.F.S.: technical and material support, critical revision; J. de H.: technical support, data analysis; J.W.P.M.van B.: study supervision, study concept and design, interpretation of data, critical revision.

Supplementary material: To access the supplementary material and Romanian abstract visit the online version of the J Gastrointestin Liver Dis at http://www.jgld.ro/wp/archive/y2016/n3/a5 and http://dx.doi. org/10.15403/jgld.2014.1121.253.rc2. 


\section{REFERENCES}

1. Verbeek RE, Leenders M, Ten Kate FJ, et al. Surveillance of Barrett's esophagus and mortality from esophageal adenocarcinoma: a population-based cohort study. Am J Gastroenterol 2014; 109: 12151222. doi: $10.1038 /$ ajg.2014.156

2. Stavrou EP, McElroy HJ, Baker DF, Smith G, Bishop JF. Adenocarcinoma of the oesophagus: incidence and survival rates in New South Wales, 1972-2005. Med J Aust 2009; 191: 310-314.

3. Guillem PG. How to make a Barrett esophagus: pathophysiology of columnar metaplasia of the esophagus. Dig Dis Sci 2005; 50: 415-424. doi: 10.1007/s10620-005-2451-x

4. Jankowski JA, Wright NA, Meltzer SJ, et al. Molecular evolution of the metaplasia-dysplasia-adenocarcinoma sequence in the esophagus. Am J Pathol 1999; 154: 965-973. doi: 10.1016/S0002-9440(10)65346-1

5. Nicholson A, Jankowski J. Acid reflux and oesophageal cancer. Recent Results Cancer Res 2011; 185: 65-82. doi: 10.1007/978-3-642-03503$6 \_4$

6. Altorjay A, Paal B, Sohar N, Kiss J, Szanto I, Sohar I. Significance and prognostic value of lysosomal enzyme activities measured in surgically operated adenocarcinomas of the gastroesophageal junction and squamous cell carcinomas of the lower third of esophagus. World J Gastroenterol 2005; 11: 5751-5756. doi: 10.3748/wjg.v11.i37.5751

7. Cheng P, Gong J, Wang T, Chen J, Liu GS, Zhang R. Gene expression in rats with Barrett's esophagus and esophageal adenocarcinoma induced by gastroduodenoesophageal reflux. World J Gastroenterol 2005; 11: 5117-5122.

8. Lowe EL, Crother TR, Rabizadeh S, et al. Toll-like receptor 2 signalling protects mice from tumor development in a mouse model of colitisinduced cancer. PLoS One 2010; 5: e13027. doi: 10.1371/journal pone. 0013027

9. Penfield JD, Anderson M, Lutzke L, Wang KK. The role of cellular senescence in the gastrointestinal mucosa. Gut Liver 2013; 7: 270-277. doi: 10.5009/gnl.2013.7.3.270

10. Szumilo J, Burdan F, Zinkiewicz K, et al. Expression of syndecan-1 and cathepsins $\mathrm{D}$ and $\mathrm{K}$ in advanced esophageal squamous cell carcinoma Folia Histochem Cytobiol 2009; 47: 571-578. doi: 10.2478/v10042-0080012-8

11. Goldman A, Chen $\mathrm{H}$, Khan MR, et al. The $\mathrm{Na}+\mathrm{H}+$ exchanger controls deoxycholic acid-induced apoptosis by a $\mathrm{H}+$-activated, $\mathrm{Na}+$-dependent ionic shift in esophageal cells. PLoS One 2011; 6: e23835. doi: 10.1371/ journal.pone. 0023835

12. Appelqvist $\mathrm{H}$, Waster $\mathrm{P}$, Kagedal $\mathrm{K}$, Ollinger $\mathrm{K}$. The lysosome: from waste bag to potential therapeutic target. J Mol Cell Biol 2013; 5: 214226. doi: $10.1093 / \mathrm{jmcb} / \mathrm{mjt} 022$

13. Boya P. Lysosomal function and dysfunction: mechanism and disease Antioxid Redox Signal 2012; 17: 766-774. doi: 10.1089/ars.2011.4405

14. Grant BD, Donaldson JG. Pathways and mechanisms of endocytic recycling. Nat Rev Mol Cell Biol 2009; 10: 597-608. doi: 10.1038/ nrm 2755

15. Gruenberg J. The endocytic pathway: a mosaic of domains. Nat Rev Mol Cell Biol 2001; 2: 721-730. doi: 10.1038/35096054

16. Kallunki T, Olsen OD, Jaattela M. Cancer-associated lysosoma changes: friends or foes? Oncogene 2013; 32: 1995-2004. doi: 10.1038/ onc.2012.292

17. Puxbaum V, Nimmerfall E, Bauerl C, et al. M6P/IGF2R modulates the invasiveness of liver cells via its capacity to bind mannose 6-phosphate residues. J Hepatol 2012; 57: 337-343. doi: 10.1016/j.jhep.2012.03.026
18. Testro AG, Visvanathan K. Toll-like receptors and their role in gastrointestinal disease. J Gastroenterol Hepatol 2009; 24: 943-954. doi: 10.1111/j.1440-1746.2009.05854.x

19. Chang CP, Su YC, Hu CW, Lei HY. TLR2-dependent selective autophagy regulates NF-kappaB lysosomal degradation in hepatoma-derived M2 macrophage differentiation. Cell Death Differ 2013; 20: 515-523. doi: 10.1038/cdd.2012.146

20. Settembre C, Di Malta C, Polito VA, et al. TFEB links autophagy to lysosomal biogenesis. Science 2011; 332: 1429-1433. doi: 10.1126/ science. 1204592

21. Jaiswal KR, Morales CP, Feagins LA, et al. Characterization of telomerase-immortalized, non-neoplastic, human Barrett's cell line (BAR-T). Dis Esophagus 2007; 20: 256-264. doi: 10.1111/j.14422050.2007.00683.x

22. Verbeek RE, Siersema PD, Ten Kate FJ, et al. Toll-like receptor 4 activation in Barrett's esophagus results in a strong increase in COX-2 expression. J Gastroenterol 2014; 49: 1121-1134. doi: 10.1007/s00535013-0862-6

23. Jin MS, Lee JO. Structures of the toll-like receptor family and its ligand complexes. Immunity 2008; 29: 182-191. doi: 10.1016/j. immuni.2008.07.007

24. Bus P, Siersema PD, van Baal JW. Cell culture models for studying the development of Barrett's esophagus: a systematic review. Cell Oncol (Dordr ) 2012; 35: 149-161. doi: 10.1007/s13402-012-0076-6

25. Bus P, Siersema PD, Verbeek RE, van Baal JW. Upregulation of miRNA-143, -145, -192, and -194 in esophageal epithelial cells upon acidic bile salt stimulation. Dis Esophagus 2014; 27: 591-600. doi: 10.1111/dote.12112

26. Das KM, Kong Y, Bajpai M, et al. Transformation of benign Barrett's epithelium by repeated acid and bile exposure over 65 weeks: a novel in vitro model. Int J Cancer 2011; 128: 274-282. doi: 10.1002/ijc.25343

27. Vandesompele J, De Preter K, Pattyn F, et al. Accurate normalization of real-time quantitative RT-PCR data by geometric averaging of multiple internal control genes. Genome Biol 2002; 3: RESEARCH0034.

28. Griffiths G, Burke B, Lucocq J. Fine structure immunocytochemistry, 6th edn. Springer-Verlag: Berlin, 1993. 2014

29. Lim DM, Narasimhan S, Michaylira CZ, Wang ML. TLR3-mediated NF-\{kappa\}B signalling in human esophageal epithelial cells. Am J Physiol Gastrointest Liver Physiol 2009; 297: G1172-G1180. doi: 10.1152/ajpgi.00065.2009

30. Uehara A, Fujimoto Y, Fukase K, Takada H. Various human epithelial cells express functional Toll-like receptors, NOD1 and NOD2 to produce anti-microbial peptides, but not proinflammatory cytokines. Mol Immunol 2007; 44:3100-3111. doi: 10.1016/j.molimm.2007.02.007

31. Huhta H, Helminen O, Lehenkari PP, Saarnio J, Karttunen TJ, Kauppila JH. Toll-like receptors 1, 2, 4 and 6 in esophageal epithelium, Barrett's esophagus, dysplasia and adenocarcinoma. Oncotarget 2016; 7: 2365823667. doi: 10.18632/oncotarget. 8151

32. Fukata M, Abreu MT. Role of Toll-like receptors in gastrointestinal malignancies. Oncogene 2008; 27: 234-243. doi: 10.1038/ sj.onc. 1210908

33. Fukata $M$, Abreu MT. Pathogen recognition receptors, cancer and inflammation in the gut. Curr Opin Pharmacol 2009; 9: 680-687. doi: 10.1016/j.coph.2009.09.006

34. Yang L, Lu X, Nossa CW, Francois F, Peek RM, Pei Z. Inflammation and intestinal metaplasia of the distal esophagus are associated with alterations in the microbiome. Gastroenterology 2009; 137: 588-597. doi: 10.1053/j.gastro.2009.04.046 
35. Yang L, Francois F, Pei Z. Molecular pathways: pathogenesis and clinica implications of microbiome alteration in esophagitis and barrett esophagus. Clin Cancer Res 2012; 18: 2138-2144. doi: 10.1158/1078-0432.CCR-11-0934

36. Macfarlane S, Furrie E, Macfarlane GT, Dillon JF. Microbial colonization of the upper gastrointestinal tract in patients with Barrett's esophagus. Clin Infect Dis 2007; 45: 29-38. doi: 10.1086/518578

37. Tsan MF. Heat shock proteins and high mobility group box 1 protein lack cytokine function. J Leukoc Biol 2011; 89: 847-853. doi: 10.1189/ jlb.0810471

38. Cario E. Toll-like receptors in inflammatory bowel diseases: a decade later. Inflamm Bowel Dis 2010; 16: 1583-1597. doi: 10.1002/ibd.21282

39. Mulder DJ, Lobo D, Mak N, Justinich CJ. Expression of toll-like receptors 2 and 3 on esophageal epithelial cell lines and on eosinophils during esophagitis. Dig Dis Sci 2012; 57: 630-642. doi: 10.1007/s10620-011-1907-4
40. Yang CN, Shiao YJ, Shie FS, et al. Mechanism mediating oligomeric Abeta clearance by naive primary microglia. Neurobiol Dis 2011; 42: 221-230. doi: 10.1016/j.nbd.2011.01.005

41. Beckham TH, Lu P, Cheng JC, et al. Acid ceramidase-mediated production of sphingosine 1-phosphate promotes prostate cancer invasion through upregulation of cathepsin B. Int J Cancer 2012; 131: 2034-2043. doi: 10.1002/ijc. 27480

42. Gopinathan A, Denicola GM, Frese KK, et al. Cathepsin B promotes the progression of pancreatic ductal adenocarcinoma in mice. Gut 2012; 61: 877-884. doi: 10.1136/gutjnl-2011-300850

43. Sato T, Stange DE, Ferrante M, et al. Long-term expansion of epithelial organoids from human colon, adenoma, adenocarcinoma, and Barrett's epithelium. Gastroenterology 2011; 141: 1762-1772. doi: 10.1053/j. gastro.2011.07.050 

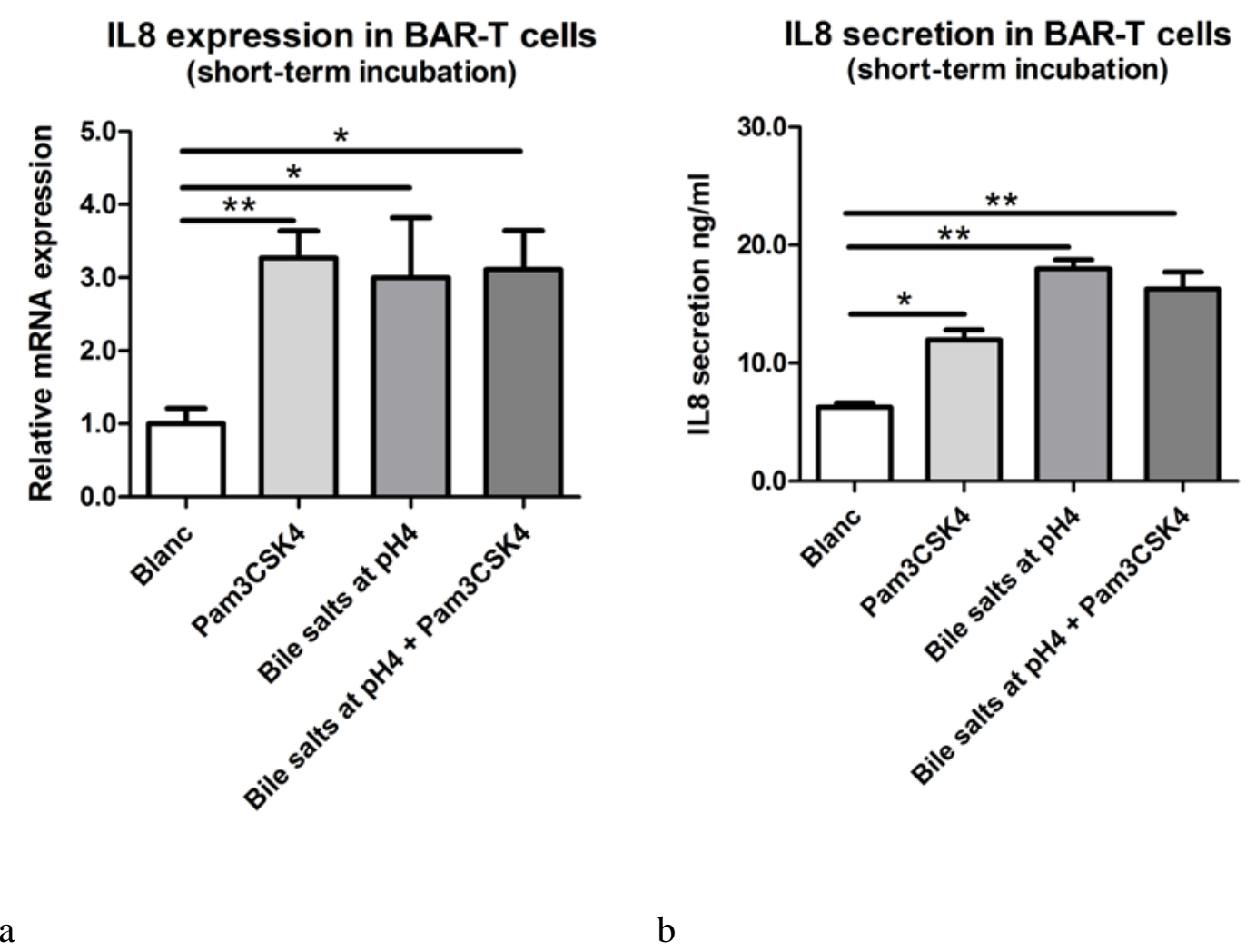

Figure 1. Short-term stimulation of BAR-T cells with the TLR2 agonist and acid and bile salts

a) Short-term (24 hours) exposure to the TLR2 agonist Pam3CSK4 and acid and bile salts mixture resulted in increased interleukin (IL) 8 mRNA expression in BAR-T cells incubated with 12.5ng/ml Pam3CSK4, with acid and bile salts (200 $\mu \mathrm{M} ; 25 \%$ DCA, 45\% GCA and 30\% TCDCA at pH 4) and with both acid and bile salts mixture and Pam3CSK4 compared to control BAR-T cells, as demonstrated by Q-RT-PCR.

b) ELISA showed an increase in IL8 secretion in the cell culture supernatant of BAR-T cells incubated with 12.5ng/ml Pam3CSK4, acid and bile salts and both Pam3CSK4 and acid and bile salts for 4 weeks compared to control cells. 


\section{Semnalizarea prin Receptorul Toll-like 2 (TLR-2) și mecanismul lizozomal în esofagul Barrett}

\footnotetext{
ABSTRACT / REZUMAT

Premize și Scop: Inflamația joacă un rol important în dezvoltarea adenocarcinomului esofagian și a leziunii sale metaplazice precursoare, esofagul Barrett. Semnalizarea prin receptorii Toll-like 2 (TLR2) și funcția lizozomală au fost considerate a avea legătură cu carcinogeneza asociată inflamației. Am examinat pe o linie celulară de esofag Barrett expresia TLR2 în esofag și efectul activării pe termen lung a TLR2 asupra modificărilor morfologice și expresiei factorilor implicaţi în funcția esofagului.

Metodă: Expresia TLR2 în biopsiile din esofagul scuamos normal, esofagita de reflux, esofagul Barrett și adnocarcinomul esofagian a fost evaluată prin Q-RT-PCR, hibridizare in situ și imunohistochimie. Celulele epiteliale ale esofagului Barrett (BAR-T) au fost incubate cu acizi și săruri biliare în prezența sau absența agonistului Pam3CSK4 al TLR2 pentru o perioadă de până la 4 săptămîni. Modificările morfologice au fost evaluate prin electronomicroscopie, iar Q-RT-PCR a fost utilizată pentru a determina expresia enzimelor lizozomale (catepsina B și C) și a factorilor implicați în endocitoză (LAMP-1 și M6PR) și autofagie (LC3 și Rab7).

Rezultate: Expresia TLR2 a fost prezentă în esofagul scuamos normal, esofagita de reflux și esofagul Barrett, dar a fost mai proeminentă în adenocarcinomul esofagian. Activarea pe termen lung a TLR2 în celulele BAR-T expuse la acizi și săruri biliare a condus la lizozomi mai mulți și mai mari, mitocondrii mai multe și o expresie crescută a LAMP-1, M6PR, catepsinei B și C în comparație cu celulele BAR-T incubate cu acizi și săruri biliare dar fără agonistul TLR2. Factorii asociați cu expresia autofagiei (LC3 și Rab7) au rămas în general nemodificați. Concluzie: Activarea TLR2 în celulele epiteliale ale esofagului Barrett expus la acizi și săruri biliare a fost urmată de creșterea numărului de mitocondrii și lizozomi și de o expresie crescută a enzimelor lizozomale și a factorilor implicați în endocitoză.
} 